\title{
LIM/Homeobox Protein Lhx4
}

National Cancer Institute

\section{Source}

National Cancer Institute. LIM/Homeobox Protein Lhx4. NCI Thesaurus. Code C98104.

LIM/homeobox protein LhX4 (390 aa, 43 kDa) is encoded by the human LHX4 gene.

This protein plays a role in the regulation of both transcription and pituitary maturation. 